16. Шелудько B.M. Фінансовий менеджмент : підручник. 2-ге вид., стер. Kиїв, 2013.375 с. URL: https://pidruchniki.com/20080215/finansi/aktivi_pidpriyemstva (дата звернення 15.04.2019).

17. Стоянова О.Г. Методологічні основи управління оборотними активами підприємства. Інвестиціï: практика та досвід. 2014. № 7. с. 7-16.

18. Константюк H., Когут I. Основні аспекти управління активами підприємства. URL: http://elartu.tntu.edu.ua/bitstream/123456789/18073/2/ConfFMNES_2016_Konstantiuk_N-Key_aspects_of_enterprise_8587.pdf (дата звернення 15.04.2019).

19. Соколов Я.В. Актив: это очень сложно. Бухгалтерскийучт-веселая наука: сборник статеи. Москва: ООО «1СПаблишинг», 2011, $638 \mathrm{c}$.

20. Мних Є.В. Економічний аналіз: підручник.

https://pidruchniki.com/1663111641846/ekonomika/ekonomichniy_analiz (дата звернення 15.04.2019).

21. Колодяжна К.С. Управління оборотними коштами торговельних підприємств в сучасних умовах. Актуальні проблеми економіки. 2015. № 19. С. 89-96.

22. Патров В.В., Ковалёв В.В. Как читать баланс. Москва: Финансы и статистика, 1991. 128 с.

23. Загальні вимоги до фінансової звітності: Національне положення (стандарт) бухгалтерського обліку 1. URL: http://zakon5.rada.gov.ua/laws/ show/z0336-13 (дата звернення 15.04.2019).

24. Про затвердження Національного положення (стандарту) бухгалтерського обліку «Загальні вимоги до фінансової звітності»: наказ Міністерства фінансів України / Кабінет Міністрів України. URL: https://zakon.rada.gov.ua/laws/show/z0336-13 (дата звернення 15.04.2019).

25. Савицька О.В. Аналіз активів підприємства. Аналіз господарськоїдіяльності підприємства. 2006. С. $438-441$.

26. Чемчикаленко P.A., Майборода О.Є., Люткіна А.В. Оцінка ефективності управління активами та пасивами підприємства. Економіка $i$ суспільство. $2017 . \quad$ Вип. №11. C. 485-489. http://www.economyandsociety.in.ua/journal/11_ukr/78.pdf (дата звернення 15.04.2019).

27. Константюк H., Когут I. Основні аспекти управління активами підприємства. URL: http://elartu.tntu.edu.ua/bitstream/123456789/18073/2/ConfFMNES_2016_Konstantiuk_N-Key_aspects_of_enterprise_8587.pdf (дата звернення 15.04.2019).

28. Ковальчук H.O. Особливості управління оборотними активами на вітчизняних підприємствах. URL: http://www.nbuv.gov.ua/portal/soc_gum/Nvbdfa/2011_1/kovalch.pdf (дата звернення 15.04.2019).

29. Петруня Н.В. Класифікація активів підприємств з урахуванням міжнародних стандартів фінансової звітності // Збірник наукових праць Національного університету державної податкової служби України, № 1, 2010. - c. 235-242. URL: http://lib.osau.edu.ua/jspui/bitstream/123456789/1339/1/28_2010_Smyrnova.pdf (дата звернення 15.04.2019).

30. Шифріна Н.I. Класифікація активів підприємства за рівнем ліквідності. Вісник економіки транспорту $i$ промисловості. 2011. № 34. С. 348-350.

Рецензент д.е.н., професор Вахович I.M.

УДК 658.15:621

Мажаренко К.П., старший викладач

Бражнікова Т.М., студентка

Кременчуцький національний університет ім. М.Остроградського

\title{
ВИЗНАЧЕННЯ МЕХАНІЗМУ АНТИКРИЗОВОГО УПРАВЛІННЯ НА ВІТЧИЗНЯНИХ ПІДПРСМСТВАХ МАШИНОБУДІВНОЇ ГАЛУЗІ
}

У статті розглядаються проблеми, які впливають на ефективність організаційно-економічного механізму антикризового управління підприємствами машинобудівного комплексу. Проводиться оцінка основних показників діяльності вітчизняного машинобудування. Авторами сформовано концепцію моделі організаційно-економічного механізму антикризового управління для підприємств даної галузі.

Ключові слова: антикризове управління, криза, діагностика, контролінг, підприємства машинобудування.

Mazharenko K., Brazhnikova T.

\section{DETERMINATION OF MECHANISM OF CRISIS-PROOF MANAGEMENT IN DOMESTIC ENTERPRISES OF MACHINE-BUILDING INDUSTRY}

The article considers problems influencing effectiveness of organizational/economic mechanism of crisisproof management in enterprises of machine-building industry. The assessment of the main indicators of domestic engineering enterprises is carried out. The conception of organizational/economic mechanism of crisis-proof management was determined for enterprises by the authors. 
Key words: crisis-proof management, crisis, diagnostics, controlling, engineering.

Мажаренко Е.П., Бражникова Т.Н.

\section{ОПРЕДЕЛЕНИЕ МЕХАНИЗМА АНТИКРИЗИСНОГО УПРАВЛЕНИЯ НА ОТЕЧЕСТВЕННЫХ ПРЕДПРИЯТИЯХ МАШИНОСТРОИТЕЛЬНОЙ ОТРАСЛИ}

В статье рассматриваются проблемы, которые влияют на эффективность организационноэкономического механизма антикризисного управления предприятиями машиностроительного комплекса. Проводится оценка основных показателей деятельности отечественного машиностроения. Авторами определена концепция модели организационно-экономического механизма антикризисного управления для предприятий данной отрасли.

Ключевые слова: антикризисное управление, кризис, диагностика, контроллинг, предприятия машиностроения.

Постановка проблеми у загальному вигляді i iї зв'язок 3 важливими науковими та практичними завданнями. Основою промислового виробництва будьякої країни є машинобудівний сектор. Важливість його стабільного розвитку полягає у тому, що на протязі багатьох століть даний сектор $\epsilon$ єдиним генератором i постачальником виробничих ресурсів на підприємства, фактично, усіх галузей. Від ступеню розвитку машинобудування, у кінцевому висновку, залежить стабільність і ефективність розвитку інших секторів і всієї економіки в цілому.

Нові економічні умови задають нові питання для дискусії про те, яким повинен бути сучасний та ефективний організаційно-економічний механізм антикризового управління. Складна економічна та політична ситуація, яка склалася в країні, вимагає нового підходу до управління. Так, враховуючи той фактор, що вітчизняна промисловість характеризується значним відставанням за технічним рівнем від розвинутих країн, важливим є дослідження проблем антикризового управління на вітчизняних машинобудівних підприємствах.

Аналіз останніх досліджень, у яких започатковано вирішення проблеми. Дослідженню питань антикризового управління на підприємстві присвячено низку робіт вітчизняних та закордонних учених-економістів. Так, особливості реалізації антикризового управління у практичній діяльності підприємств досліджуються у працях іноземних вчених: С. Беляєва, П. Друкера, А.Градова, А. Грязнова, В. Кузіна, М. Мескона, Й. Шумпетера. Серед українських економістів варто відзначити таких учених, як М. Бойко, С. Войтко, О. Гавриш, В. Герасимчук, В. Дергачова, Н. Сгорова, О. Кузьмін, Л. Лігоненко, В. Мартиненко, Л. Ситник, О. Терещенко, М. Туган-Барановський, А. Чернявський та ін.

Цілі статті. Оцінка основних показників діяльності вітчизняного машинобудування та визначення концепції моделі організаційно-економічного механізму антикризового управління для підприємств даної галузі.

Виклад основного матеріалу дослідження 3 повним обгрунтуванням отриманих наукових результатів. Висока напруженість української економіки та висока конкуренція між товаровиробниками призводять до того, що підприємства легко потрапляють під критерії банкрутства. Організаційно-економічний механізм антикризового управління підприємством являє собою систему заходів по реформуванню механізму антикризового управління у відповідності до вимог, які формуються внутрішнім та зовнішнім середовищем підприємства на сучасному етапі економічного розвитку. Кінцевою задачею формування організаційно-економічного механізму антикризового управління має стати його ефективна модель, яка б дозволяла коректувати діяльність підприємства у відповідності з метою стійкого і прогресивного розвитку. Модель організаційно-економічного механізму повинна відображати систему 
заходів з розвитку підприємства та враховувати інтереси як самого підприємства, так $\mathrm{i}$ території, і держави.

3 точки зору сьогоднішньої економічної ситуації найважливішою метою для вітчизняних підприємств стає прагнення до виживання. Така мета дійсно стає основоположною, і від іiі досягнення залежить реалізація й інших цілей господарюючого суб'єкта. У кризисній ситуації прагнення до виживання домінує над іншими цілями, а підприємство з усіх сил намагається триматися на плаву, коли фактично подальша його доля виявляється передбаченою, оскільки за збереженням себе як діючого суб' єкта економіки керівництво підприємства забуває про необхідність створювати умови для власного розвитку в перспективі. Так, як правило, ніхто не проводить аналіз впливу внутрішніх та зовнішніх факторів на своє підприємство і тим паче не проводить реінжиніринг бізнес-процесів, не переглядає організаційну структуру і т.д. Хоча у такій ситуації необхідно чітко розуміти, що стало передумовою такого положення господарюючого суб'єкта на сьогоднішній день, вплив яких факторів необхідно знизити, щоб вийти на новий рівень розвитку [1]. Ураховуючи те, що економічна сутність процесу створення організаційно-економічної моделі антикризового управління полягає у динамічному процесі перетворення й інтеграції існуючих методів обліку, аналізу, планування, контролю й координації на єдину систему одержання, обробки інформації та прийняття на іiі основі управлінських рішень, доцільно зупинитися на оцінці статистичних даних підприємств галузі машинобудування.

Згідно Держстату України, протягом 2009-2018 рр. після виходу української економіки зі світової економічної кризи, обсяг реалізованої промислової продукції поступово збільшувався, питома вага галузі машинобудування у загальному обсязі також мала тенденцію до зростання ( у 2009 р. - 85,8; у 2018 р. - 181,7 млрд.грн) (рис.1). Але у 2013 році спостерігається падіння обсягів реалізованої продукції промисловості, і до 2016 року зменшення питомої ваги машинобудування в структурі промислової продукції України (з 10,3\% у 2012 р. до 6,1\% у 2016 р.). 32017 року прослідковується збільшення як обсягу промислової продукції, так і продукції машинобудування, зростає питома вага галузі (у 2017 p. - 6,4\%, у 2018 p. - 7,2\%).

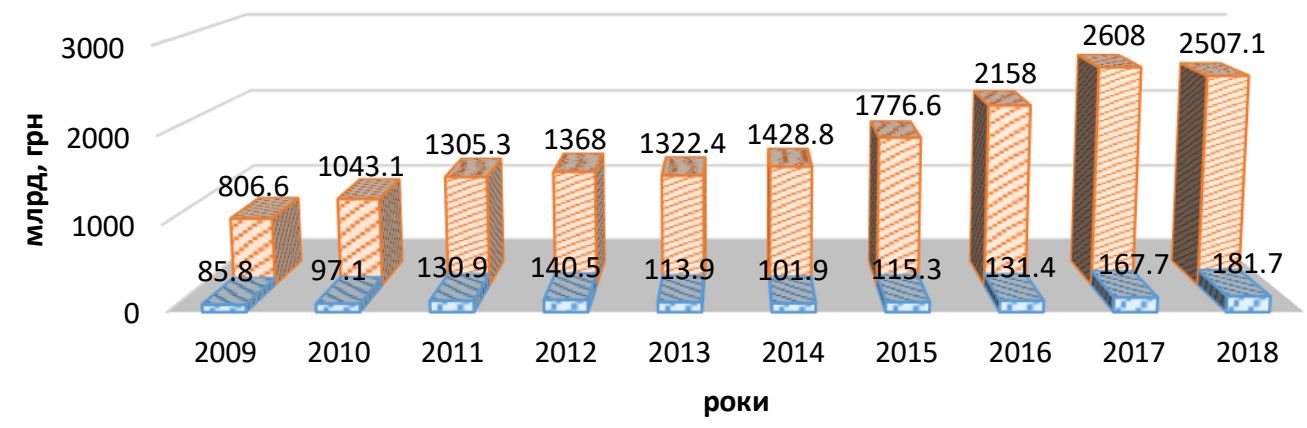

Обсяг реалізованої продукції машинобудування

Обсяг реалізованої промислової продукції

Рис. 1. Основні показники розвитку промисловості України за період 2009-2018pp.

За даними Держстату України, у виробництві продукції машинобудівних підприємств (рис.2) у 2009 році спостерігається кризовий спад виробництва, після чого 
у 2010 році різке зростання. У період з 2011-2014 рр. прослідковується падіння обсягів виробництва, поступове зростання у 2015-2017 рр., та знову спад у 2018 році. Такі коливання та загалом негативна динаміка пояснюється кризовою ситуацією та неефективністю заходів розвитку машинобудівних підприємств в Україні.

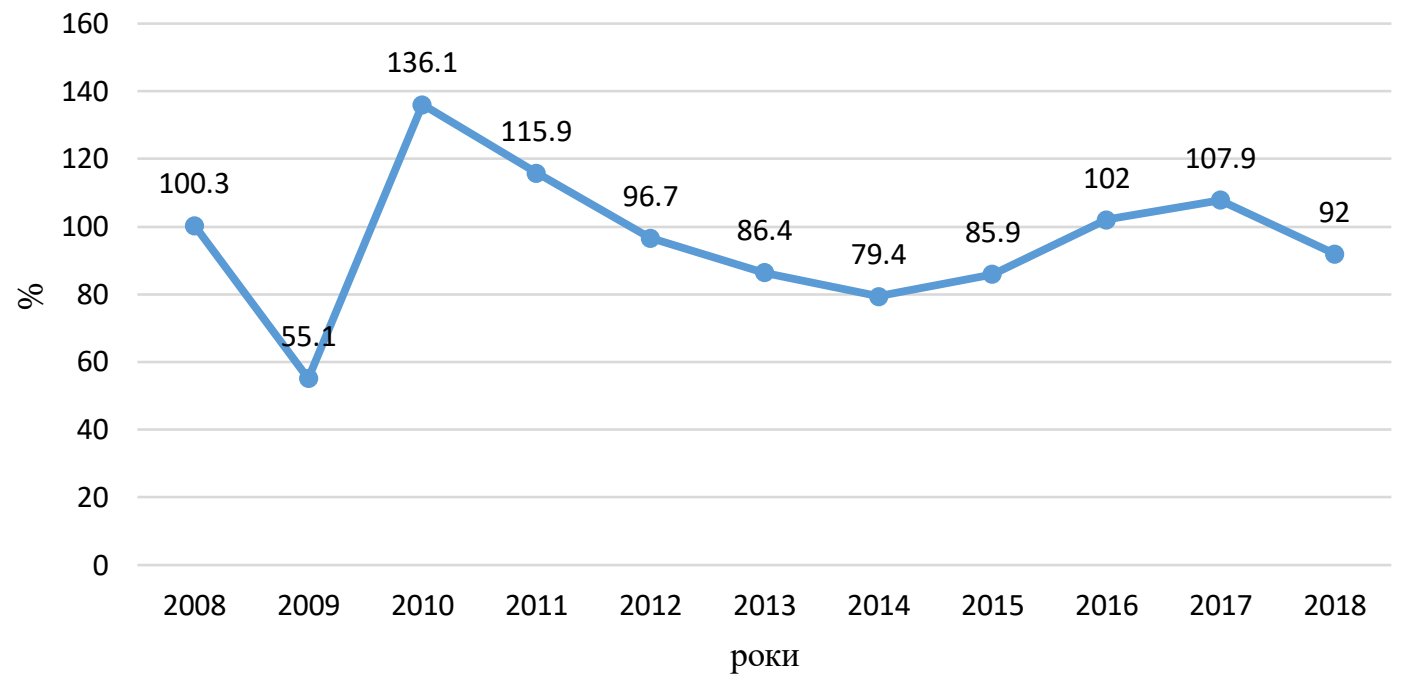

Рис. 2. Динаміка індексів обсягів продукції машинобудування

В економічно розвинутих країнах машинобудування займає близько 30-50\% у загальному обсязі виготовленої продукції в промисловості. Так, в Німеччині даний показник складає 53,6\%, в Японії - 51,5\%, у Великобританії - 39,6\% [2]. Саме такий рівень розвитку галузі може забезпечити технічне переоснащення промисловості кожні 7-10 років. У нашій країні цей показник становить 7,2\% (станом на 2018 рік) [3]. Це і є основною причиною відставання вітчизняної промисловості від промисловості розвинутих країн за технічним рівнем.

До провідних підприємств галузі машинобудування в м. Кременчук відносять: ПАТ «Крюківський вагонобудівний завод», ПрАТ «АвтоКрАЗ», ПрАТ «Кременчуцький колісний завод», ПрАТ «Кредмаш». В українському просторі лідируючі позиції 3 виготовлення вантажних автомобілів займає приватне акціонерне товариство «АвтоКрАЗ». Динаміка виробництва автомобілів на кременчуцькому підприємстві $\epsilon$ невтішною. У 2014 році завод випустив 1388 грузовиків (600 з яких необхідні для обслуговування силових структур). У 2016 році об'єм виробництва скоротився до 800 штук, у 2017 році виробили вже 629 КрАЗів. Динаміка за 2018 рік не перевищила $+5 \%$ у порівнянні з попереднім роком (військове замовлення склало лише близько 100 машин). «АвтоКрАЗу» важко конкурувати на українському ринку через те, що державні структури частіше закупають імпортні грузовики. Але, у цілому, ПрАТ «АвтоКрАЗ» у змозі виконувати у повному обсязі свої зобов'язання перед державою по сплаті податків, не зважаючи на падіння машинобудування і зовнішні фактори, які впливають на стабільну роботу підприємства. Так, у 2018 році платежі підприємства у держбюджет становили близько 121 млн.грн., що на 11\% більше аналогічного показника у 2017 році. Як і всі вітчизняні промислові підприємства, ПрАТ «АвтоКрАЗ» переживає гострий дефіцит кадрів, зокрема молодого покоління, більшість з яких виїхала закордон.

Таким чином, виділені типові проблеми, які впливають на ефективність організаційно-економічного механізму антикризового управління підприємствами даної галузі:

1. Відсутність системи моніторингу факторів зовнішнього середовища i господарської діяльності підприємств. 
2. Відсутність задокументованої стратегії розвитку і системи планування, яка б відповідала поточній ринковій ситуації, пов'язаної зі зниженням попиту на продукцію.

3. Високий знос основних фондів і відсутність фінансування для їх заміни; нестача власних коштів та низька інноваційна активність.

4. Відсутність обгрунтованої інвестиційної політики.

На основі досліджень, проведених авторами, було виділено основні напрями концепції створення організаційно-економічного механізму антикризового управління у складних умовах трансформації економічних відносин:

1. Проведення предикативного аналізу зовнішнього та внутрішнього середовища на предмет наявності передумов для виникнення кризових ситуацій.

2. Здійснення превентивної, глобальної діагностики показників фінансовогосподарської діяльності підприємства і показників ефективності. Діагностика повинна мати комплексний характер і проводитися із заданою періодичністю.

3. Пріоритетність стратегії розвитку, а не виживання. У передкризовому стані підприємства віддають перевагу стратегії виживання, у той час як життєдіяльність підприємства буде залежати від того, наскільки ефективно воно може використовувати фактори кризи для подальшого розвитку. У цьому підприємству можуть допомогти інновації, які будуть сприяти нарощенню конкурентних переваг [4]. Менеджмент інновацій повинен бути основним елементом стратегії підприємства.

На думку Й. Шумпетера, основою економічного розвитку $є$ нововведення. У відповідності до розробленої ним класифікації нововведення представляють собою:

- запуск у виробництво нового продукту або підвищення якості товарів 3 асортименту продукції підприємства;

- освоєння нового ринку збуту, на якому продукція підприємства ще не була представлена;

- використання нового джерела сировини;

- уведення нового способу виробництва на основі досягнень наукового прогресу;

- проведення реорганізації [5].

4. Необхідність оцінки ресурсного потенціалу. Оцінюючи ресурсний потенціал у процесі реалізації механізму антикризового управління, необхідно звернути увагу на такі параметри як достатність ресурсів для вирішення поставлених задач, гнучкість, перспективність та адаптивність ресурсного потенціалу. Важливою проблемою для вітчизняних підприємств $є$ високий рівень зносу основних фондів і відсутність фінансування для їх заміни.

5. Відповідність організаційної структури новим потребам середовища. У нелегкий для підприємства час стає особливо важливо модернізувати організаційну структуру і привести ії у відповідність новій обраній стратегії.

6. Застосування методу контролінгу як інструменту цілеорієнтованого управління. Контролінг розглядається як інструмент управління організацією, який направлений на координацію роботи всіх підсистем менеджменту і контролю над їх ефективністю [6] і $\epsilon$ невід'ємною частиною системи антикризового управління будь-яким підприємством.

7. Застосування методики оцінки ефективності реалізації механізму антикризового управління. Така оцінка може здійснюватися 3 використанням таких критеріїв оцінки ефективності: результативність і фінансова ефективність; гнучкість та адаптивність; інноваційний потенціал та інноваційна ефективність. 
Таким чином, на основі концептуальних положень із вдосконалення організаційноекономічного механізму антикризового управління пропонується

Рис. 3. Модель організаційно-економічного механізму антикризового управління підприємством

використовувати процесну модель організаційно-економічного механізму антикризового управління на підприємстві, яка складається із дев'яти блоків (рис.3).

Така структура моделі дозволяє адаптувати організаційно-економічний механізм антикризового управління до динамічних умов середовища, підвищуючи ефективність системи управління і фінансово-господарської діяльності підприємства.

Реалізація представленої у статті моделі організаційно-економічного механізму антикризового управління $є$ пріоритетною 3 точки зору сьогоднішньої економічної ситуації, оскільки такий механізм має превентивний характер заходів, направлений на закріплення позиції підприємства, підвищення його конкурентоспроможності. Коректування механізму антикризового управління повинно здійснюватися шляхом реалізації ряду управлінських заходів, які направлені на постійне вдосконалення антикризового управління для покращення адаптації підприємства до висококонкурентного ринкового середовища:

1. Моніторинг і оцінка показників ефективності діяльності підприємства у процесі реалізації організаційно-економічного механізму антикризового управління.

2. Дослідження помилок і негативних результатів діяльності.

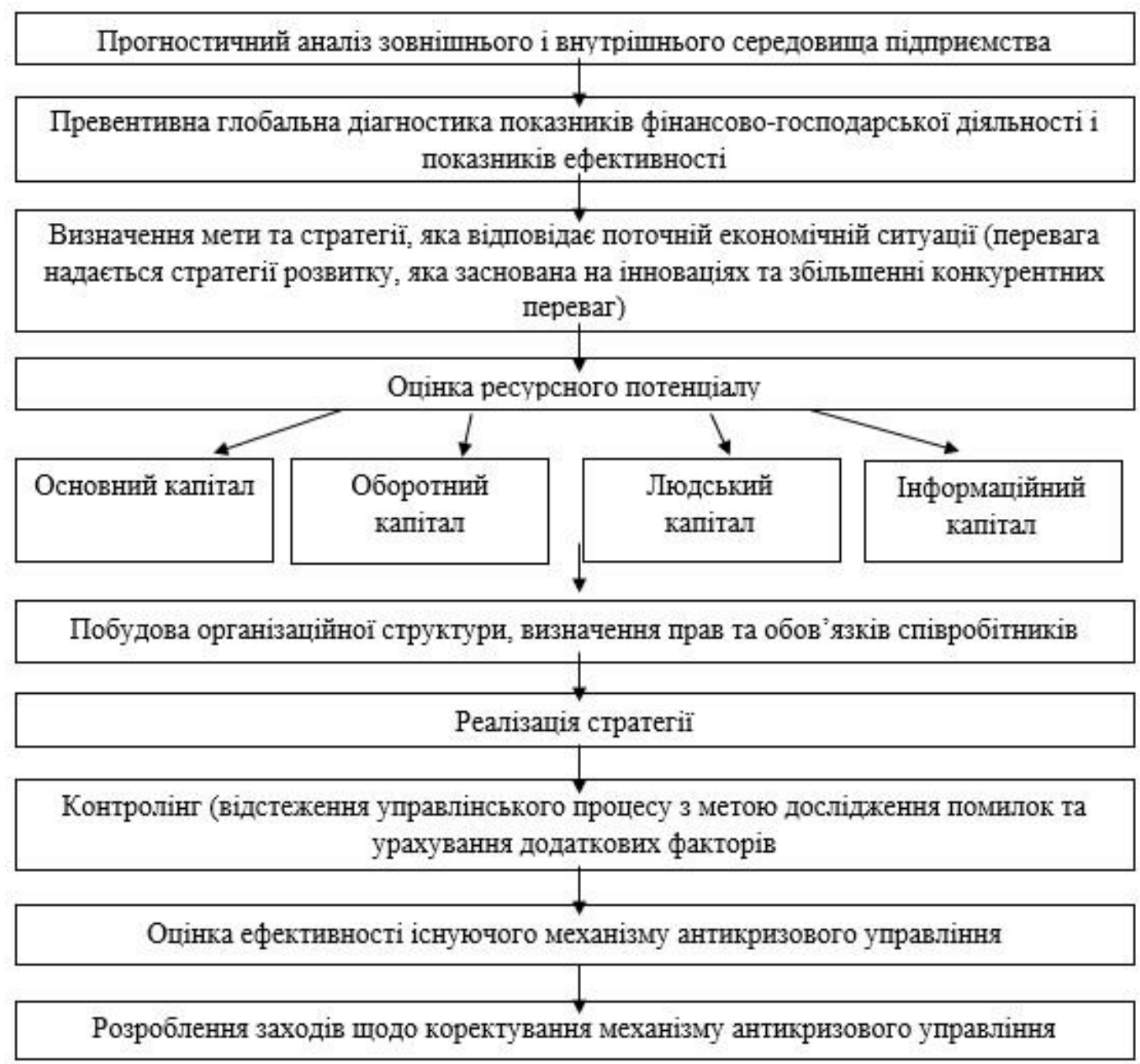

3. Облік додаткових факторів і введення нових параметрів оцінки.

4. Введення інновацій у процес антикризового управління. 
5. Коректування організаційно-економічного механізму антикризового управління.

Висновки. Таким чином, у даний час кризисні ситуації на машинобудівних підприємствах обумовлені відсутністю систем контролінгу і моніторингу, оцінки впливу зовнішніх та внутрішніх факторів на стан галузі. Чим менше інформації про стан середовища має підприємство, тим більша вірогідність впливу кризисних умов на його діяльність. Саме тому при удосконаленні організаційно-економічного механізму антикризового управління необхідно приділяти особливу увагу превентивній діагностиці показників фінансово-господарської діяльності і показників ефективності діяльності підприємства, а також оцінці ефективності вже сформованого механізму антикризового управління. Застосування запропонованої моделі організаційноекономічного механізму антикризового управління дозволить вчасно відслідковувати несприятливі тенденції в діяльності підприємства, зможе зробити кризисний процес більш керованим і дасть можливості використовувати фактори кризи на користь якісного розвитку підприємства.

\section{Список використаних джерел:}

1. Борзенко В. І. Антикризове управління. Харків, 2016. 232 с.

2. Барташевська Ю.М. Розвиток машинобудування України: стан, проблеми, перспективи. Свропейський вектор економічного розвитку. 2010. №1 (8). С. 19-25.

3. Державна служба статистики України [Електронний ресурс] - Режим доступу до ресурсу: http://www.ukrstat.gov.ua.

4. Шершньова Є. 3. Антикризове управління підприємством. Київ, 2000.

5. Шумпетер Й. А. Теория экономического развития. Москва. 1982. 455 с.

6. Пыткин А.Н., Кондратьева К.В. Эффективная модель организационно-экономического механизма антикризисного управления промышленным предприятием. Вестник Пермского университета. Сер. «Экономика». 2016. №1(28). С. 138-146.

Рецензент д.е.н., професор Хоменко М.М.

УДК 336:004.896(07)

Пиріг С.О., к.е.н., доцент

Луцький національний технічний університет

\section{ВИКОРИСТАННЯ ЗВЕДЕНИХ ТАБЛИЦЬ ЕХСЕL ДЛЯ АНАЛІЗУ ДАНИХ У ПРОФЕСІЙНІЙ ДІЯЛЬНОСТІ ПІДПРИСМСТВА}

У статті здійснено дослідження особливостей використання інструменту зведених таблиць MS Excel, для аналізу даних з метою підвищення інформаційної компетентності у професійній діяльності фахівців.

Ключові слова: MS Excel, програмне забезпечення, зведені таблиці, професійна діяльність фахівця, інформаційна компетентність.

Pyrih S.

\section{USE EXCEL SUMMARY TABLES FOR ANALYSIS OF DATA IN PROFESSIONAL ACTIVITY OF THE ENTERPRISE}

In the article, a study was conducted of the features of using the MS Excel PivotTable tool for data analysis in order to increase information competence in the professional activities of specialists.

Keywords: MS Excel, software, summary tables, professional activity of a specialist, information competence.

Пыриг C.A. 